\title{
Parental Support, Academic Emotion, Learning Strategy, and Academic Achievement on First Year Student
}

\author{
Rizky Amalia $^{1 *}$ Melly Latifah ${ }^{2)}$ \\ ${ }^{1,2}$ Department of Family and Consumer Sciences, Faculty of Human Ecology, IPB \\ University, Bogor 16680, Indonesia \\ ${ }^{*}$ Corresponding author: catatan.kiky@gmail.com
}

\begin{abstract}
The new challenges for first-year students potentially to influence their academic achievement. This study aimed to analyze the characteristics of students and families, parental support, academic emotions, and learning strategies and their correlation to the academic achievement of first-year students. Determination of research location by purposive at Institut Pertanian Bogor. An example of this study is a total of 110 students of the Program Pendidikan Kompetensi Umum (PPKU) selected by simple random sampling. The results found that emotional and instrumental aspects of parental support, positive activating, negative activating and deactivating academic emotions were significantly correlated with learning strategies. Furthermore, time and environment management and effort learning correlated on academic achievement.
\end{abstract}

Keywords: academic emotion, academic achievement, learning strategy, parental support.

\begin{abstract}
Abstrak
Berbagai tantangan baru bagi mahasiswa tingkat pertama berpotensi memengaruhi capaian akademik di awal perkuliahan. Penelitian ini bertujuan untuk menganalisis karakteristik mahasiswa dan keluarga, dukungan orang tua, emosi akademik, dan strategi belajar serta hubungannya dengan prestasi akademik mahasiswa tingkat pertama. Penentuan lokasi penelitian secara purposive di Institut Pertanian Bogor. Contoh pada penelitian ini sebanyak 110 mahasiswa Program Pendidikan Kompetensi Umum (PPKU) dipilih dengan simple random sampling. Hasil penelitian menemukan bahwa dukungan orang tua secara emosional dan instrumental, emosi akademik positif aktivasi, negatif aktivasi dan negatif deaktivasi berhubungan signifikan dengan penggunaan strategi belajar. Selanjutnya, pengaturan waktu dan lingkungan tempat belajar serta upaya dalam belajar berhubungan dengan prestasi akademik.
\end{abstract}

Kata kunci: dukungan orang tua, emosi akademik, prestasi akademik, strategi belajar 


\section{Introduction}

The education program aims to develop the potential of students thus, they are expected to be able to contribute to the broader community in the future. The Act No.20/2003 concerning the National Education System states that education is a deliberate and planned effort to create a learning atmosphere and learning process, therefore, students actively develop their potential to have spiritual strength, selfcontrol, personality, intelligence, noble character, and the skills needed by their own, the community, and the country. Academic achievement is one of the benchmarks for knowing students' ability to assimilate lessons and indicators of success in achieving educational goals. Academic achievement is an indicator of learners' self-adaptation to school and future success (Jelas et al., 2016).

The standard of each college determines the assessment of student academic accomplishment. The data is compiled in the University Statistics Book by the Kemenristekdikti (Ministry of Research and Higher Education). Kemenristekdikti (2018) released a book enclosing higher education institutions, study programs, new students, registered students, dropout students, and graduates in any given period and showed that as many as 2.8 percents of students in Indonesia were dropped out of college although the figure was reduced from 2014-2015, but still in a large number of 195,176 out of $6,924,511$ students.

Several prior studies examined factors that influence academic achievement. Research stated that there is a significant relationship between social support from parents on children's performance (Maslihah, 2011). Ronaldo (2013) also revealed that parental support has a substantial effect on learning outcomes. Theory of social support (Sarafino \& Smith, 2010) describes social support in the form of attention, appreciation, or the availability of assistance for someone from another person or group, in this case, the parental support. Parental support is related to emotional problems, the higher the support of parents, the smaller the issues faced by children (Helsen et al., 1997).

Academic emotions are the emotions that emerge in various learning conditions and are directly related to the process of achieving aspirations (Pekrun et al., 2011). Pekrun's research, et. Al (2002) stated that academic emotions are significantly related to student motivation, learning strategies, cognitive resources, self-regulation, and academic achievement. The emotion of joy and pride moderates the relationship of selfregulation in learning with achievement. The part of self-regulation in this study is learning strategy. The prior explanation showed the importance of the role of emotions and the benefit of learning strategies during learning activities on academic processes and achievements in adolescents (Pekrun et al., 2007; Pekrun et al., 2011).

However, other studies have found that social support and academic achievement can be attributed to the influence of academic achievement through mediator variables (Situmorang \& Latifah, 2014). Other studies suggest that some mediator variables of social support, such as learning strategies, motivation, and trust, will affect one's self-competence (Ahmed et al., 2013). Each learner uses learning strategies in achieving their goals. Research by Situmorang and Latifah (2014), Novianti (2014), Novita and Latifah (2014), Citrandini and Hernawati (2016) found that the advantage of proper learning strategies could improve the adolescent's academic achievement.

Other factors that influence academic achievement are characteristics of children such as girls who have better academic performance than boys (Novita \& Latifah, 2014; Citrandini \& Hernawati (2016). Socio-economic factors derived from parents' education 
are shown by Situmorang and Latifah (2014) research that parental education has a significant positive influence on the use of self-regulation strategies in learning. Caprara et al. (2008) stated that socio-economic status, income, and parental education have a direct influence on achievement academic.

Based on the explanation, the authors are interested in knowing and analyzing the role of parent support, academic emotion, and learning strategies on the academic achievement of first-level students in one of the public university of West Java. Therefore, the purpose of this study was to (1) find out the characteristics of students and families, parental support, academic emotions, learning strategies, and academic achievements the students; (2) analyze the relation between student and family characteristics, parental support, academic emotions with learning strategies; and (3) analyze the relationship between dimensions of learning strategies with academic achievement.

\section{Methods}

This study used a cross-sectional study design conducted at one of the public universities in West Java. Determination of the location of the study was carried out using a purposive method. The population of this study was first-level students amounting 3.794 people. Sampling is done by probability sampling method with a simple random sampling technique. Determination of the number of samples using the Slovin formula with an error rate of 0.1 percent resulted in as many as 98 students. Consider 10 percent of the population as a reserve respondent. Thus, the total sample is 110 students.

Student and family characteristics data were collected using a questionnaire that included gender, age and parents, monthly allowance, parental education level, and per capita income. The entire variable questionnaire uses a Likert scale $(1=$ very inappropriate; $2=$ not appropriate; $3=$ appropriate; and $4=$ very appropriate).

Parental support is the attitude, action, and acceptance of individuals or groups, which means parents to a child. Parental support consists of three dimensions, namely, emotional, instrumental, and informational support. Emotional support is in the form of encouragement, a sense of empathy and assistance as long as the child goes through college in the first year. Instrumental support is support in the form of direct material things, such as the provision of facilities and infrastructure. Informational support is support in the form of direction, provision of information, knowledge by parents related to lectures and career paths for students during the first six months of the lecture. The parent support questionnaire was developed from the theory of social support (Sarafino \& Smith, 2010) consisting of 21 statements divided into three parts namely emotional support (6 statements), instrumental (10 statements), and informational (5 statements) with Cronbach's alpha 0.870 .

Academic emotion is emotion when involved in learning activities with their initiative, which is divided into positive activating, negative activating, and negative deactivating. Positive academic emotion activation is when students feel able to attain academic achievement and consider it essential so what will emerge is the emotion of happiness, hope and pride. Academic emotion is negative activating when students feel unable to go through and achieve academic achievement and consider it. It is crucial that emotions emerge like anger, anxiety, and shame. Academic emotions are negative deactivating when students feel unable to go through and achieve academic 
achievement and assume that this is not important so that emotions will emerge such as hopelessness and boredom. Academic emotion was measured by adapting a questionnaire entitled Achievement Emotion Questionnaire (Pekrun et al., 2002) which measured positive and negative emotions when the example of self-study with a total of 75 statements with Cronbach's alpha 0.897.

Learning strategies are strategies used by students when the learning process takes place, covering nine dimensions, namely: repetition, elaboration, organization, critical thinking, self-regulation metacognition, time management or learning environment, business arrangements in learning, group learning and seeking help. Learning strategies are measured using the Motivated Strategies for Learning Questionnaire (MSLQ) by Pintrich et al., (1991), which consists of 50 statements with Cronbach's alpha 0.832 .

Academic achievement is mastery or understanding of knowledge, and academic abilities as seen from the first-semester achievement index measured using the firstsemester achievement index scores obtained from the Directorate of higher education. The data analysis used was the descriptive test and Pearson correlation.

\section{Findings}

\section{Student Characteristics}

The results showed that the number of female students is higher $(54.5 \%)$ than male students (45.5\%). If the respondents grouped according to their ages, more than half of respondents aged 18 years $(59.09 \%)$ and the rest distribute at the age of 17-20 years. The average monthly income of respondents is the total of pocket money and scholarships of IDR 1.230.000. Nearly one-third of students have pocket money per month in the range of IDR 1.000.000 - IDR 2.000.000.

\section{Family Characteristics}

There are almost 1 in 20 students that the fathers have died (4.5\%). The age distribution of students' parents was divided based on age. The age grouping refers to Santrock (2010), where almost all of the parents were in the category of middle-aged (40-65) years, i.e. father (93.6\%) and mother (92.7\%). Research shows that there are parents of students who do not have formal education, specifically 4.5 percent of fathers and 1.8 percent of mothers. The highest level of parents' education is at the high school level, both fathers $(35.5 \%)$ and mothers $(33.5 \%)$. The second largest category was undergraduate, fathers $(23.6 \%)$ and mothers $(31.8 \%)$. The average length of education of fathers and mothers is relatively the same, namely 12.81 and 12.60 years. Data on per capita income distribution per month are categorized based on the Indonesian Poverty Line (BPS, 2017), which is below IDR 400.995 said to be poor (14.5\%).

\section{Parental Support}

In this parental study, support consisted of emotional, instrumental, and informational support. The category is low, fair, and high, describing the amount of parental support for the condition of the respondent during the first semester of the lecture. 


\section{Emotional support}

Table 1 shows Nearly half of the students (47.3\%) received high emotional support. Students feel that parents appreciate each goal achieved (56.4\%), parents express pride and praise (48.2\%), parents make time to tell stories (50.9\%).

\section{Instrumental support}

The results showed that more than half of the students felt that they had relatively high instrumental support. First-degree students felt that parents provided laptops as a learning tool (53.6\%), paid dormitory money (60.9\%), and provided money for meals during college $(61.8 \%)$ (Table 1$)$.

\section{Informational support}

As many as 61.0 percents of students felt less on informational support (Table 1). Students perceive that parents only have provided knowledge about college majors and job opportunities (35.5\%), become discussion partners (48.2\%), help finishing on difficult tasks (29.1\%), and are willing to answer questions related to lectures $(37.3 \%)$.

Table 1 Distribution of PPKU IPB students based on parents' support during the first semester of lecture

\begin{tabular}{|c|c|c|c|c|c|c|}
\hline \multirow[t]{2}{*}{ Parental Support } & \multicolumn{2}{|c|}{$\begin{array}{c}\text { Low } \\
(0-60)\end{array}$} & \multicolumn{2}{|c|}{$\begin{array}{c}\text { Fair } \\
(60-<80)\end{array}$} & \multicolumn{2}{|c|}{$\begin{array}{c}\text { High } \\
(80-100)\end{array}$} \\
\hline & $\mathrm{n}$ & $\%$ & $\mathrm{n}$ & $\%$ & $\mathrm{n}$ & $\%$ \\
\hline Parental Support & 9 & 8.2 & 64 & 58.2 & 37 & 33.6 \\
\hline Emotional support & 11 & 10 & 47 & 42.7 & 52 & 47.3 \\
\hline Instrumental support & 3 & 2.7 & 48 & 43.7 & 59 & 53.6 \\
\hline Informational support & 67 & 61 & 27 & 24.5 & 16 & 14.5 \\
\hline
\end{tabular}

\section{Academic Emotion}

The academic emotions studied in this study are the emotions that are felt when studying. Low, medium and high categories describe the frequent appearance of these emotions when studying. Grouping academic emotions based on control value theory (Pekrun, 2006). The grouping is based on valence degrees (positive> <negative) and activation (activation> < deactivation). Grouping based on valence degrees is influenced by student control of him.If students feel able to control themselves and can achieve their goals in learning, positive emotions emerge.

Conversely, if students feel unable, then negative emotions emerge. Grouping based on activation is influenced by valuation or value. If students think the learning process and achievements are essential to him, then what appears is activation. Conversely, if the learning process and achievements are not necessary to him, then what emerges is deactivation.

Overall, the average positive activating emotions that occurs when independent learning is more often than negative activating and negatif deactivating. It was shown on Table 2 that more than half of students looking forward to the time to study (56.4\%), enjoying challenges in lecture material (70\%), optimistic about an increase (80\%), and being proud of their abilities (78\%). However, students feel the learning process is upsetting (57.3\%), feel disturbed when they learn too much (10.9\%), feel scared since they cannot understand the material $(64 \%)$.), Shame if they do not understand the material $(83.6 \%)$. Negative deactivating emotion such as students feel hopeless when 
thinking about learning (13.6\%), feel resigned when they have learned but also do not understand it $(31 \%)$, and feel that hopelessness undermines all existing strength $(47.3 \%)$.

Table 2 The distribution of PPKU IPB students based on academic emotions arose from independent learning

\begin{tabular}{lrrrrrr}
\hline \multirow{2}{*}{ Academic Emotion } & \multicolumn{2}{c}{$\begin{array}{c}\text { Seldom } \\
(0-60)\end{array}$} & \multicolumn{2}{c}{$\begin{array}{c}\text { Occasionally } \\
(60-<80)\end{array}$} & \multicolumn{2}{c}{$\begin{array}{c}\text { Often } \\
(80-100)\end{array}$} \\
\cline { 2 - 8 } & $\mathrm{n}$ & \multicolumn{1}{c}{$\%$} & $\mathrm{n}$ & \multicolumn{1}{c}{$\%$} & $\mathrm{n}$ & \multicolumn{1}{c}{$\%$} \\
\hline Positive Activating & 17 & 15.5 & 77 & 70.0 & 16 & 14.5 \\
$\quad$ Enjoyment & 19 & 17.3 & 74 & 67.3 & 17 & 15.4 \\
Hope & 11 & 10.0 & 70 & 63.6 & 29 & 26.4 \\
Pride & 32 & 29.1 & 58 & 52.7 & 20 & 18.2 \\
\hline Negative Activating & 103 & 93.6 & 6 & 5.5 & 1 & 0.9 \\
Anger & 107 & 97.3 & 2 & 1.8 & 1 & 0.9 \\
Anxiety & 101 & 91.8 & 8 & 7.3 & 1 & 0.9 \\
Shame & 67 & 60.9 & 37 & 33.6 & 6 & 5.5 \\
\hline Negative Deactivating & 102 & 92.7 & 7 & 6.4 & 1 & 0.9 \\
Hopelessness & 99 & 90.0 & 10 & 9.1 & 1 & 0.9 \\
Boredom & 96 & 87.3 & 13 & 11.8 & 1 & 0.9 \\
\hline
\end{tabular}

\section{Learning Strategies}

Learning strategies are part of a self-regulating learning strategy that is categorized as low, medium, and high. Low categories mean that students use strategies that are still less varied. The higher the score indicates, the more and often the strategy used when learning. The overall results of the study showed that one-third of students $(33.3 \%)$ still used a low learning strategy, almost two-thirds $(63.1 \%)$ of students were categorized as being moderate, and the rest $(2.7 \%)$ students carried out various learning strategies (Table 3).

More than three-quarters of students (77.3\%) classified as low in the dimensions of peer learning mean that students rarely spend time studying and discussing together the lecture material. Another finding is that more than half of the students are still categorized as being in five learning strategies, namely elaboration, critical thinking, metacognition, learning time management, and business settings. There is one of three students still not varied enough in using the learning strategy (33.3\%), almost two out of three students use a learning strategy that is quite varied (63.1\%), and few students have carried out various learning strategies $(2.7 \%)$.

There were more than 1 in 3 students not making a list of essential items and not memorizing the keywords (39.1\%), more than half of the students did not use their study time well (50.9\%), and it was challenging to manage the study schedule $(61.9 \%)$. Students rarely discuss with other students $(70 \%)$ and do not explain lecture material to their friends $(41.8 \%)$, but still ask friends to disclose when they do not understand $(91.8 \%)$. Besides, students already have the usual place for learning $(84.6 \%)$, and almost all $(92.8 \%)$ still do their best even though they do not like the material being taught. 
Table 3 Distribution of PPKU IPB students based on the use of learning strategies

\begin{tabular}{|c|c|c|c|c|c|c|}
\hline \multirow[t]{2}{*}{ Learning Strategy } & \multicolumn{2}{|c|}{$\begin{array}{c}\text { Low } \\
(0-60)\end{array}$} & \multicolumn{2}{|c|}{$\begin{array}{c}\text { Moderate } \\
(60-<80)\end{array}$} & \multicolumn{2}{|c|}{$\begin{array}{c}\text { High } \\
(80-100)\end{array}$} \\
\hline & $\mathrm{n}$ & $\%$ & $\mathrm{~N}$ & $\%$ & $\mathrm{n}$ & $\%$ \\
\hline Learning Strategy & 37 & 33.3 & 70 & 63.1 & 3 & 2.7 \\
\hline Rehearsal & 50 & 45.5 & 49 & 44.5 & 11 & 10.0 \\
\hline Elaboration & 26 & 23.6 & 74 & 67.3 & 10 & 9.1 \\
\hline Organization & 40 & 36.4 & 53 & 48.2 & 17 & 15.5 \\
\hline Critical thinking & 33 & 30.0 & 67 & 60.9 & 10 & 9.1 \\
\hline Metacognitive self-regulation & 39 & 35.5 & 69 & 62.7 & 2 & 1.8 \\
\hline $\begin{array}{l}\text { Time and study environmental } \\
\text { management }\end{array}$ & 53 & 48.2 & 56 & 50.9 & 1 & 0.9 \\
\hline Effort regulation & 35 & 31.8 & 64 & 58.2 & 11 & 10.0 \\
\hline Peer learning & 85 & 77.3 & 24 & 21.8 & 1 & 0.9 \\
\hline Help-seeking & 46 & 41.8 & 51 & 46.4 & 13 & 11.8 \\
\hline
\end{tabular}

\section{Academic Achievement}

Academic achievement in this study is seen from the first-semester Grade Point Average (GPA). The GPA is categorized into five, namely conditional $(\leq 1.70)$, pass (1.71 - 1.99), satisfactory $(2.00-2.75)$, good (2.76 - 3.50) and very good (3.51 - 4.00). This category is adjusted to the Data from the PPKU Directorate of IPB (2017). The lowest category is said to be conditional because it is not safe from the minimum drop out. The overall results of the study showed that the average students' GPA (3.01) was categorized as good. In the category it can be seen that more than half of the students (56.4\%) get good categorical GPA, as many as a quarter of students $(25.5 \%)$ are categorized satisfactory, one per eight students (12.7\%) are categorized very good, almost one in twenty students $(4.5 \%)$ categorized as pass, and $(0.9 \%)$ categorized as conditional.

\section{Correlation}

The results of the Pearson correlation test between the characteristics of students and families, parental support, academic emotions, and learning strategies showed a relationship between several variables. Parental support especially emotional and instrumental support is positively correlated with learning strategies. That is, the higher the support provided, the more strategic and varied strategy use when the students are learning.

Positive activating of academic emotions have a significant positive correlation with learning strategies in all dimensions, namely enjoyment, hope, and pride. While negative acctivating and deactivating were significantly negatively correlated with learning strategies, mainly the aspects of anger, hopelessness, and boredom. That is, the more often the positive activating and the less frequent negative emotions (activating and deactivating) that arise when learning, the learning strategies used are more varied. The overall support of parents and the dimensions of parental support variables, namely emotional and instrumental, positively related to positive activating and its dimensions, namely enjoyment and hope and learning strategies.

Conversely, it is negatively correlated with negative activating that is the anger dimension. Similarly, negative deactivating also have a significant negative correlation with overall parental support, parental support for emotional and informational 
dimensions have a significantly positive relationship with positive activating. The results of the correlation test between parents' support, academic emotions, and learning strategies can be seen in Table 4.

Table 4 The relationship between parental support, academic emotions, and learning strategies

\begin{tabular}{crrrrr}
\hline \multicolumn{1}{c}{ Variable } & $\begin{array}{r}\text { Parental } \\
\text { Support }\end{array}$ & $\begin{array}{c}\text { Emotional } \\
\text { Support }\end{array}$ & $\begin{array}{c}\text { Instrumental } \\
\text { Support }\end{array}$ & $\begin{array}{c}\text { Informational } \\
\text { Support }\end{array}$ & $\begin{array}{c}\text { Learning } \\
\text { Strategy }\end{array}$ \\
\hline Positive Activating & $0.313^{* *}$ & $0.345^{* *}$ & $0.307^{* *}$ & 0.057 & $0.633^{* *}$ \\
Enjoyment & $0.325^{* *}$ & $0.393^{* *}$ & $0.282^{* *}$ & 0.079 & $0.612^{* *}$ \\
Hope & $0.283^{* *}$ & $0.258^{* *}$ & $0.350^{* *}$ & -0.006 & $0.544^{* *}$ \\
Pride & 0.182 & $0.207^{*}$ & 0.157 & 0.059 & $0.442^{* *}$ \\
\hline Negative Activating & -0.109 & -0.017 & -0.116 & -0.117 & $-0.282^{* *}$ \\
Anger & $-0.289^{* *}$ & $-0.252^{* *}$ & $-0.292^{* *}$ & -0.109 & $-0.437^{* *}$ \\
Anxiety & -0.034 & 0.063 & -0.099 & -0.011 & -0.163 \\
Shame & 0.039 & 0.127 & 0.087 & -0.162 & -0.105 \\
\hline Negative Deactivating & $-0.220^{*}$ & $-0.238^{*}$ & -0.121 & $-0.196^{*}$ & $-0.433^{* *}$ \\
Hopelessness & -0.172 & -0.138 & -0.137 & -0.136 & $-0.387^{* *}$ \\
Boredom & $-0.230^{*}$ & $-0.304^{* *}$ & -0.078 & $-0.225^{*}$ & $-0.399^{* *}$ \\
\hline Learning Strategy & $0.231^{*}$ & $0.192^{*}$ & $0.226^{*}$ & 0.111 & 1 \\
\hline
\end{tabular}

Note: ${ }^{*}=$ significant at $\mathrm{p}<0.05 ;{ }^{* *}=$ significant at $\mathrm{p}<0.01$.

The correlation between the dimensions of the learning strategy towards academic achievement was found that the more effective the timing and environment of the learning place carried out by students, and the much effort made when studying, the higher academic achievement that the students would attain. Other dimensions are rehearsal, elaboration, organization, critical thinking, metacognitive self-regulation, peer learning, help-seeking found not significantly related to the strategy when learning used is independent learning. The results of the correlation test between the dimensions of learning strategy and academic achievement can be seen in Table 5.

Table 5 Correlation test table between dimensions of learning strategy and academic achievement

\begin{tabular}{lr}
\hline Learning Strategy Dimensions & Academic Achievement \\
\hline Learning Strategy & 0.168 \\
Rehearsal & .069 \\
Elaboration & .154 \\
Organization & .134 \\
Critical thinking & .124 \\
Metacognitive self-regulation & .043 \\
Time and study environmental management & $\mathbf{. 2 5 0} * *$ \\
Effort regulation &. $\mathbf{2 5 2} * *$ \\
Peer learning & -.093 \\
Help-seeking & .046 \\
\hline
\end{tabular}

\section{Discussion}

Santrock (2013) stated that in the developmental stages of adolescence, the achievement is an important affair, and adolescents feel more challenged in academic improvement. Achievement influenced by not only a person's intelligence but also the other internal and external factors that influence it. The results of the study showed that 
there were no characteristics of adolescents and parents that significantly affected learning strategies and academic achievement. The results of this study are contrary to the results of the research showing that girls have better academic performance than boys (Novita \& Latifah, 2014; Citrandini \& Hernawati, 2016) and parental education has a significant positive influence on the use of self-regulation strategies in learning. (Situmorang \& Latifah, 2014).

Another factor that is thought to affect academic achievement is the support of parents. Support from parents will predict essential criteria such as success and academic achievement during the first and second years when entering lectures (Cutrona et al., 1994). The results showed that overall parental support was positively related to learning strategies. In particular parental support that is positively related to learning, strategies are emotional support and instrumental support while informational support is not related. Chowa, Masa, and Tucker (2013) study stated that adolescents who have good academic achievement are also good parents. The dimensions of parental support that are positively related to academic achievement are emotional support. Emotional support brings empathy, attention, concern, positive outlook, and enthusiasm for someone (Sarafino \& Smith, 2010).

These findings are in line with the results of research by Cutrona et al. (1994) that high academic achievement among students can discuss their interests and interests in parents and parents who believe in children's abilities. Wolf, Sax, and Harper (2009) research reveals that first-degree students may also need more closeness with their parents because they have just left home to study compared to more senior students. Support for informational dimensions of parents is known to be very low. It is assumed that students are in the stage of adolescence, which prefers to find information to friends or the internet compared to parents. Apart from that, the knowledge and education of parents who are different from the world of their children's lectures at this time cannot help children in matters related to work assignments. Moreover, first-degree students must live in a dormitory for one full year, which results in having to part temporarily with parents, so that there is still a need for adaptation to many things.

Academic emotions are emotions that occur during the learning process. The emotions that most often arise in this study are positive activating. Following the research of You and Kang (2014) that positive activating is associated with significant learning strategies. The results showed that the higher the positive emotions, the learning strategies used were also increasingly varied. By Pekrun et al. (2011) which stated that positive emotions such as comfort, hope, and pride could increase intrinsic and extrinsic motivation, easily adjust the use of learning strategies, and support selfregulation, thereby positively influencing academic achievement. Other studies suggest that positive activating show a significant influence on learning strategies (Citrandini \& Hernawati, 2016). If the three dimensions of positive emotions increase, most of the learning strategies dimensions will increase. By the research of Ahmed, et al. (2013) stated that at the beginning of the level of positive activating emotions such as comfort and pride predict an increase in the use of learning strategies and changes in comfort and pride also anticipate changes in learning strategies. Another case with negative academic emotions was found to have an inverse relationship with learning strategies and academic achievement. These negative emotions are anger, hopelessnesss, and boredom. The more negative emotions emerge, the learning strategies used are not diverse. Learning strategies that are not distinct give rise to negative emotions such as boredom. Pekrun et al. (2011) stated that negative emotions such as hopelessness and 
boredom could reduce motivation and information processing, which indirectly lowers achievement. Negative academic emotions have a negative relationship with almost all dimensions of the learning strategy.

In particular, the dimensions of boredom are significantly negative related to learning strategies and GPA. Pekrun et al. (2011) stated that boredom was negatively associated with related to students' academic control behavior, learning motivation, use of learning strategies, self-regulation strategies in learning, and academic achievement. Zimmerman (1990) identified learning strategies with self-regulation obtained from social cognitive theory. Each strategy aims to improve students' self-regulation on personal, behavioral, and environmental functions. The results of the study showed that first-degree students were good enough in the regulation of personal purposes, evidenced by the use of learning strategies, rehearsal, effort regulation, and mediumterm elaboration strategies. The behavioral function regulation section in which students evaluate themselves by re-examining the lessons that have been obtained and think about the consequences of what they have done is also quite good as seen from the distribution of answers to the dimensions of critical thinking and metacognitive selfregulation. Whereas in the environmental function, there are still many low categorized students in the search for free time to discuss with their peers and ask the instructor when they have not understood the concept of a subject matter.

The dimensions of learning strategies that relate significantly to academic achievement are time and study environmental management or the timing and environment of learning and effort regulation. Zimmerman (1990) mentions that learning arrangements involve limited strategies or responses, efforts made by students to initiate and regulate themselves proactively, such as preparation for study time, readiness, and effort in learning.

Overall, learning strategies have been shown to influence academic achievement, especially in these two dimensions. It is learning strategies such as finding comfortable learning places, arranging regular learning schedules, always taking the time to read, and reviewing reading before the test proved to be able to improve academic achievement. Besides, the effort to always do the best, never give up and keep trying to understand the material even though it is complicated is also proven to improve achievement. This research is by previous research conducted by Situmorang and Latifah (2014), Novianti and Latifah (2014), Novita and Latifah (2014), Citrandini and Hernawati (2016) which state that the use of learning strategies can improve adolescent academic achievement.

\section{Conclusion and Recommendation}

\section{Conclusion}

The results revealed that instrumental and emotional parental support was higher than informational support. Positive activating emotions appear predominantly than negative emotions. The use of learning strategies carried out by respondents is in the moderate category for all dimensions except peer learning, which is still low. Respondents use more of the strategy of organization, elaboration, and effort regulation.

The results of the correlation test show that the support of parents' emotional and instrumental dimensions and all dimensions of positive emotions have a real directional relationship to the learning strategy whereas all dimensions of negative emotions except shame have an inverse and real relationship with learning strategies. Test of correlation 
with achievement index shows that the dimensions of learning strategies, namely the management of time and study environment and the effort of learning related to academic achievement.

\section{Recommendation}

Based on the results of the study, there are three suggestions for higher education institutions.

1. Making a program carried out at the beginning of the admission of new students to convey essential things related to cooperation with parents including the delivery of the importance of the role of support for people in the early lectures.

2. Give attention to the emotional condition of students when independent learning. This can be realized in the counseling program held by universities.

3. It is facilitating students to recognize the many learning strategies that can be used by conducting training on the use of learning strategies for PPKU students.

Also, it performs academic, emotional recognition of PPKU students, so that the learning effort can be carried out maximally, and the learning process to be more enjoyable. Suggestions for students are to use diverse learning strategies to avoid boredom and create a sense of happiness and enthusiasm in learning. In particular, students must have a high fighting spirit in learning lecture material even though it is considered very difficult. Also, students should manage their time and allocate their own space for learning to create a conducive learning atmosphere. It should be remembered for students, that the success of achievement at the first level can spur the continuity of lectures at the next level. Suggestions for further research to combine other variables such as self-regulated learning (motivation and learning strategies), friends' and teacher's support, and academic emotions associated with classroom learning and examinations. Besides, measuring academic achievement is not only based on GPA but can be by combining report cards or student intelligence based on IQ scores.

\section{References}

Ahmed et al. (2013). Emotions, self-regulated learning, and achievement in mathematics:A growth curve analysis. Journal of Educational Psychology, 105(1), 15.

[BPS] Badan Pusat Statistik. (2017). Garis Kemiskinan Menurut Provinsi 2013-2017. Retrieved from: https://www.bps.go.id/linkTableDinamis/view/id/1120. [diunduh 30 Maret 2018].

Caprara, G. V., Fida, R., Vecchione, M., Del Bove, G., Vecchio, G. M., Barbaranelli, C., \& Bandura, A. (2008). Longitudinal analysis of the role of perceived selfefficacy for self-regulated learning in academic continuance and achievement. Journal of educational psychology, 100(3), 525.

Chowa, G., Masa, R., \& Tucker, J. (2013). The effects of parental involvement on the academic performance of Ghanaian youth: Testing measurement and relationship using structural equation modeling. Children and Youth Services Review, 35(12), 2020-2030. DOI:10.1016/j.childyouth.2013.09.009

Citrandini, M. dan Hernawati, N (2016). Emosi akademik, strategi belajar, dan prestasi akademik siswa sma di wilayah perdesaan. Jurnal Ilmu Keluarga dan Konsumen, 195-205 
Cutrona, C. E., Cole, V., Colangelo, N., Assouline, S. G., dan Russell, D. W. (1994). Perceived parental social support and academic achievement: an attachment theory perspective. Journal of Personality and Social Psychology, 66(2), 369-378.

Direktorat Program Pendidikan Kompetensi Umum. (2017). Program Pendidikan Kompetensi Umum dalam Angka. Diambil dari: http://ppku.ipb.ac.id/tpb-dalamangka. [diunduh 20 November 2017]

Helsen, M., Vollebergh, W., dan Meeus, W. (2000). Social support from parents and friends and emotional problems in adolescence. Journal of Youth and Adolescence, 29(3), 319-335.

Jelas, Z. M. (2016). Learning support and academic achievement in the malaysian adolescent.

Learning Environ Res 19:221-240. DOI: 10.1007/s10984-015-9202-5

Maslihah, S. (2011). Studi tentang hubungan dukungan sosial, penyesuaian sosial di lingkungan sekolah dan prestasi akademik siswa SMPIT Assyfa Boarding School Subang Jawa Barat. Jurnal Psikologi, 10(2), 103-114.

Novianti, N dan Latifah, M. 2014. Pengaruh gaya pengasuhan, motivasi, dan strategi pengaturan diri dalam belajar terhadap prestasi akademik remaja. [skripsi]. Institut Pertanian Bogor, Bogor, Indonesia.

Novita, L dan Latifah, M. (2014). Strategi pengaturan diri dalam belajar sebagai mediator harapan orang tua dan motivasi intrinsik terhadap prestasi akademik. Jurnal Ilmu Keluarga dan Konsumen, 7(2). 143-153.

Papalia, D. E., Olds, S. W. (1981). Human Development. New York, NY: McGraw-hill Book Company. 2nd ed.

Pekrun, R., Goetz, T., Titz, W., Perry, R. P. (2002). Academic emotions in students' self-regulated learning and achievement: a program of qualitative and quantitative research. Educational Psychologist, 37, 91-105.

Pekrun, R., Frenzel, A. C., Goetz, T., \& Perry, R. P. (2007). The control-value theory of achievement emotions: An integrative approach to emotions in education. In Emotion in education (pp. 13-36).

Pekrun, R., Goetz, T., Frenzel, A. C., Barchfeld, P., dan Perry, R. P. (2011). Measuring emotions in students' learning and performance: The Achievement Emotions Questionnaire (AEQ). Contemporary educational psychology, 36(1), 36-48.

Pintrich, P. R., De Groot, E. V. (1990). Motivational and self-regulated learning components of classroom academic performance. Journal of Educational Psychology. Vol 2 (1), 33-40

Ronaldi, R. (2013). Pengaruh dukungan orang tua dan kemandirian belajar terhadap hasil belajar ekonomi siswa kelas XI IPS SMAN 6 Padang. Jurnal Pendidikan Ekonomi, 2(2).

Sarafino, E. P., \& Smith, T. W. (2011). Stress, biopsychosocial factors, and illness. In Chapter IV. Health Psychology: Biopsychosocial Interactions (pp.80-109). John Wiley \& Sons, Inc

Situmorang, Z. R. D., dan Latifah, M. (2014). Pengaruh dukungan sosial, konsep diri, dan strategi pengaturan diri dalam belajar terhadap prestasi akademik. Jurnal Ilmu Keluarga dan Konsumen, 7(3), 154-163.

Santrock, J. W. (2013). Adolescence Fifthteen Edition. United States of America, USA: McGraw-Hill Education.

Undang-Undang, R. I. (2003). No. 20 Tahun 2003. Tentang Sistem Pendidikan Nasional, 9. 
Wolf, D. S. S., Sax, L., \& Harper, C. E. (2009). Parental engagement and contact in the academic lives of college students. Naspa Journal, 46(2), 325-358. DOI: 10.2202/1949-6605.6044.

You, J. W. dan Kang, M. (2014). The role of academic emotions in the relationship between perceived academic control and self-regulated learning in online learning. Computers \& Education. DOI: 10.1016/j.compedu.2014.04.018.

Zimmerman, B. J. (1990). Self-regulated learning and academic achievement: An overview.Educational Psychologist. 25(1):3-17. DOI: 10.1207/s15326985ep2501_2 